\title{
Social determinants of overweight and obesity in the mother-child binomial: evidences from Mexico
}

\author{
Armando Arredondo, Christian Torres, Emanuel Orozco and Oscar Resendiz
}

\begin{abstract}
Background: To analyze the influence of socioeconomic determinants on the development of overweight and obesity in the mother-child binomial.

Methods: This is a study based on a prospective cohort of the mother-child binomial. Using STATA software, the association between the mothers' body mass index and the nutritional status of minors was analyzed using a logistic regression model with socioeconomic and demographic variables.

Results: The combined prevalence of overweight and obesity in cohort mothers was 53.2\%. A statistically significant association was found between the overweight mothers and minors with possible risk of overweight ( $p$ 0.001 ) and with overweight ( $p$ 0.001). The logistic regression model was adjusted by age and marital status and linked maternal overweight and obesity with the following variables: severe food insecurity (RR 1.17, Cl 0.04-1.31), having a health problem (RR 1.5, Cl 0.86-2.05), income (RR 0.79, Cl .49-1.30), smoking (RR 1.1, Cl 0.80-1.37) and dietary pattern (RR 1.5, Cl 0.38-1.87).

Conclusions: The study highlights the importance of paying attention to risk factors starting at the gestational stage, since at this time the mother's nutritional status has an influence on the offspring's growth and development. Evidences exist of an association between intergenerational transmission of obesity and socioeconomic aspects of the mother. These evidences must be considered in the revision and adjustments to health system interventions for the prevention of obesity in the mother-child binomial.
\end{abstract}

Keywords: Maternal obesity, Child obesity, Socioeconomic determinants, Dietary patterns, Food security

\section{Background}

Overweight and obesity are the fastest growing public health problems in developing countries and Mexico is a middle income country with rapid epidemiological and nutritional transitions [1,2]. According to the 2012 and 2016 National Health and Nutrition Surveys (ENSANUT), the prevalence of these conditions has increased in women of reproductive ages, from 71 to $75 \%$, respectively $[3,4]$.

\footnotetext{
* Correspondence: ciss09@insp.mx

National Institute of Public Health, Av. Universidad 655, CP 61100 Cuernavaca, Mor, Mexico

(c) The Author(s). 2020, corrected publication [2020] Open Access This article is licensed under a Creative Commons Attribution 4.0 International License, which permits use, sharing, adaptation, distribution and reproduction in any medium or format, as long as you give appropriate credit to the original author(s) and the source, provide a link to the Creative Commons licence, and indicate if changes were made. The images or other third party material in this article are included in the article's Creative Commons licence, unless indicated otherwise in a credit line to the material. If material is not included in the article's Creative Commons licence and your intended use is not permitted by statutory regulation or exceeds the permitted use, you will need to obtain permission directly from the copyright holder. To view a copy of this licence, visit http://creativecommons.org/licenses/by/4.0/. The Creative Commons Public Domain Dedication waiver (http:// creativecommons.org/publicdomain/zero/1.0/) applies to the data made available in this article, unless otherwise stated in a credit line to the data. evidence has also shown that the mothers' nutritional
}

Today there is interest in the specific life periods during which diverse environmental exposures induce physiological and anatomical changes, and these in turn can lead to health risk factors. One of the critical periods for women is gestation, where specially their pregestational and gestational body mass indexes (BMI) have an influence on the offsprings' nutritional status $[5,6]$.

The associations between nutritional status in early childhood and future risk of chronic diseases have been well studied; these associations may be linked to genetic or environmental factors during pregnancy [7-9]. The 
status [10-12], has an impact on the offspring's nutritional status.

Overweight and obesity are multifactorial diseases and socioeconomic factors have become part of the explanation of these conditions. There is evidence that sociodemographic aspects, health-related beliefs and socioeconomic status have an influence on the selection of cheap foods that are high in calories, as well as having less access to healthcare and to healthy foods [11-14]. These factors, together with the demographic, epidemiologic and nutritional transitions, are the main causes of the increase in the prevalence of overweight and obesity.

This investigation was derived from the NUTTSEA $[15,16]$ cohort, which began in 2017. The sample size was determined by the number of women who sought prenatal care, since week 24 of the gestational period, at a regional referral hospital in the state of Morelos, Mexico. The study's objective was to analyze the influence of socioeconomic factors related to health disparities, on risks of chronic diseases for mothers and children.

This document shows the findings of the second stage of the NUTTSEA cohort, in order to analyze the influence of socioeconomic determinants on the development of maternal overweight and obesity, and to evaluate these conditions in view of the association of overweight and obesity in their children.

\section{Methods}

This study was based on a cohort type design that was also prospective, analytical and explanatory. The study population consists of the mothers who belong to the NUTTSEA cohort and their children $[15,16]$. The universe of study included all pregnant women who requested services for prenatal care during the first semester of 2017, at a regional hospital for uninsured population. The study population was determined by a simple random sampling with statistical power of $90 \%$ in the sample size and confidence level of 95\%. Pregnant women were included who fulfilled the following criteria: having 24 weeks of gestation or more, living in municipalities near the referral hospital (within a $10 \mathrm{~km}$ radius), being over 18 years old and not having plans to move in the short/medium term. We excluded all women who were less than 18 years old, who reported alcohol or tobacco consumption during pregnancy, and who had a history of a disease that could block their inclusion in the study (mental health, amputation, sexually transmitted diseases, blood group incompatibility, etc.).

The data used in the present study were collected by means of quantitative questionnaires directed to the participating mothers. The interviewers who were responsible for the collection of information have training in nutrition and were trained and standardized in anthropometry of adults and children under 2 years of age.

\section{Socioeconomic - demographic data}

A questionnaire was applied with 19 multiple choice questions pertaining to geographic data, as well as data on location, contact, age, marital status, religion, occupation, household income and membership in social programs.

\section{Diet}

Dietary information was obtained by means of a food frequency questionnaire with 103 foods divided into groups and including information on food consumption during the 7 days prior to the application of the questionnaire. In order to obtain dietary patterns, each food was analyzed to determine its composition (kcal, carbohydrates, proteins, lipids, grams and fiber), using the Mexican system of equivalents. 25 food groups were obtained according to their nutritional characteristics.

\section{Food security}

In order to determine the food security indicators, the Latin American Food Security Scale [17] was used. In this scale there are key questions that people face during a certain time period in their homes, pertaining to food availability, access, use and stability.

\section{Anthropometry}

The mothers' anthropometric weight-height measurements were taken in order to determine the BMI $(\mathrm{kg} /$ $\mathrm{m}^{2}$ ). That indicator, was then classified into low weight $(<18.5)$, normal weight (18.5-24.9), overweight (25$29.9)$ and obesity (>30).

The minors' nutritional status was evaluated by means of three indicators which are: length by age (L/A), weight by age (W/A) and weight by length (W/L). The $\mathrm{z}$ score was figured by age and sex, for the whole study population, according to the World Health Organization's (WHO) reference pattern, and was classified as: malnutrition (severe, moderate and mild), normal, possible risk of overweight (PROW), overweight and obesity. The minors were measured during the first year of their lives. For this purpose, a tray scale was used, parents were asked to remove the child's clothes, only leaving on a clean diaper. An infantometer was used for the length measurement and with the help of the mother, the anthropometrist made the measurement. The Antro Plus software was used to obtain the diagnosis of the three indicators measured in the minors.

\section{Data processing and analysis}

The categorical and continuous data were presented as percentages and means, respectively. A bivariate analysis 
was carried out to know the relation between the mothers' gestational and post-pregnancy nutritional status and the minors' nutritional status. A chi2 test was done and the $p<0.05$ value was considered as statistically significant, with confidence intervals of $95 \%$.

The logistic regression model estimated the odds ratio of being overweight and obese and confidence intervals were $95 \%$. Values that were considered to be statistically significant were equal to or under $0.05,0.01$ and 0.001 . Maternal BMI was the control variable, categorized as normal/overweight+obesity, adjusting for variables like age, marital status, occupation, family income and total income, educational level, tobacco consumption, alcoholism, municipality of residence and food safety.

To determine dietary patterns, a factor analysis by principal components was carried out with orthogonal rotation (1.6 varimax), which identified the patterns depending on the factor points. Factor loading (>0.3) showed the importance of a food or food group in a pattern's definition. Factor loading, variance (eigenvalues > 1.6) for each factor and the interpretability of each component were the elements considered in order to decide the number of extracted factors.

\section{Results}

The findings of the NUTTSEA cohort show data on 396 women, 1 year after the first data collection. These results are divided into three spheres: 1) socioeconomic, which includes economic and demographic population variables; 2) health, which includes health and nutrition status of the mother-child binomial, and 3) food, food security and diet.

\section{Socioeconomic-demographic characteristics of women in the NUTTSEA cohort}

We found that the mean age was 26 years, $63.2 \%$ of women lived in common-law marriage, $52.3 \%$ had junior high school as their last year of schooling, 80.5\% were housewives and only $8.6 \%$ had paid work; monthly income from paid work was 91 U. S dlls. In $88.7 \%$ of cases, the head of household is the interviewee's partner and of these, 89\% had a paid job with a monthly income of 146 dlls.

With respect to household income in dollars, $14.7 \%$ reported having a monthly income of 119 dlls coming from another family member, $9.9 \%$ said they received an income of 30 dlls from a social program to which they belonged, and the total household income was calculated as being 207 dlls. $18.2 \%$ of the interviewees reported belonging to a social program, being PROSPERA the one that was mentioned the most. With respect to health insurance, 97.8\% had the Seguro Popular.

\section{Health}

Anthropometric measurements taken after pregnancy show that the mean weight was $59.7 \mathrm{~kg}$ (SD $12.7 \mathrm{~kg}$ ), height was $1.53 \mathrm{~m} \mathrm{(SD} 0.5 \mathrm{~m}$ ) and BMI was 25.2 (SD 5.1 ), this last one being three points under the one reported during pregnancy, which was 28 (SD 4.7); however, during pregnancy, the gestational BMI was taken as the cohort point.

Using the BMI (Table 1) as an indicator of the women's nutritional status, we see that $6.9 \%$ of women have low body weight, $39.8 \%$ have normal weight, $32.9 \%$ are overweight and $20.3 \%$ are obese. When comparing to the nutritional status they had during pregnancy, $18.1 \%$ had low weight, $32 \%$ had normal weight, $31.1 \%$ were overweight and $18.6 \%$ were obese; thus, we can see an increase in overweight and obesity in the postpregnant women.

With respect to minors, a first evaluation was carried out according to the following indicators: weight/age (W/A), length/age (L/A) and weight/length (W/L); this last one was used as a reference point in the nutritional diagnosis (Table 3). 57.5\% were boys and $42.5 \%$ were girls; the mean reported age in months was $7.35 \pm 2.08$, for both sexes. Regarding the minors' anthropometric data, we found that mean weight was $7.74 \pm 1.07 \mathrm{~kg}$ and mean length was $67.30 \pm 5.42$, for both sexes.

With respect to $\mathrm{W} / \mathrm{L}$, this indicator was taken as a diagnostic criterion for the minors' nutritional status; $14.72 \%$ had mild malnutrition, $3.03 \%$ had moderate malnutrition, $0.87 \%$ had severe malnutrition, $67.53 \%$ had a normal nutritional status, $7.79 \%$ were in PROW (Possible Risk of Overweight), 5.63\% were overweight and $0.43 \%$ had been diagnosed as being obese (Table 2 ).

\section{Food, food security and diet}

ELCSA findings show that $46.3 \%$ had food security, $38.1 \%$ had mild food insecurity, $10.8 \%$ had moderate food insecurity and $4.7 \%$ had severe food insecurity. That is, 53.6\% suffered from some degree of food insecurity at home. We find evidence that food security is a public health problem, since more than half of our population saw their food limited due to lack of economic resources.

With respect to the dietary analysis, three main components were determined that explain $27 \%$ of total variance in consumption. Loading factors $(>0.3)$ for the three identified patterns are shown in Table 3; a pattern was created, based on three food groups. The pattern of industrialized foods and fats was characterized by consumption of soups (0.30), processed meats (0.35), fats (0.36) and snacks (0.37) and showed a negative load for plain water (0.39). The Western pattern was characterized by consumption of fruits (0.38), sugared cereals (0.30), products derived from corn (0.32) and high fat 
Table 1 Anthropometric characteristics of cohort NUTTSEA breasts

\begin{tabular}{|c|c|c|c|c|c|}
\hline & Category & $\begin{array}{l}\text { Media } \pm \text { Standar Deviation, } \\
\text { Average } \\
2017^{b}\end{array}$ & Cl 95\% & $\begin{array}{l}\text { Media, Standar Deviation, } \\
\text { Average } \\
2018^{\mathrm{a}}\end{array}$ & Cl 95\% \\
\hline Weight & $\mathrm{Kg}$ & $66.9 \pm 12.1$ & $\begin{array}{l}65.37- \\
68.53\end{array}$ & $59.7 \pm 12.7$ & $\begin{array}{l}58.08- \\
61.38\end{array}$ \\
\hline Size & M & $1.54 \pm 0.5$ & $1.53-1.55$ & $1.53 \pm 0.5$ & $1.53-1.54$ \\
\hline Body mass index (BMI) & $\mathrm{Ms} / \mathrm{kg}^{2}$ & $27.9 \pm 4.8$ & $\begin{array}{l}27.50- \\
28.45\end{array}$ & $25.2 \pm 5.1$ & $\begin{array}{l}24.55- \\
25.87\end{array}$ \\
\hline \multirow{4}{*}{$\begin{array}{l}\text { Nutritional diagnosis according to } \\
\text { BMl }\end{array}$} & Under weight & 18.1 & $0.13-0.23$ & 6.9 & $0.04-0.11$ \\
\hline & $\begin{array}{l}\text { Normal } \\
\text { weight }\end{array}$ & 32 & $0.26-0.38$ & 39.8 & $0.33-0.46$ \\
\hline & Overweight & 31.1 & $0.25-0.37$ & 32.9 & $0.27-0.39$ \\
\hline & Obesity & 18.6 & $0.14-0.24$ & 20.3 & $0.15-0.26$ \\
\hline
\end{tabular}

\footnotetext{
${ }^{a}$ Anthropometry taken 1 year after its first intervention
}

${ }^{\mathrm{b}}$ Nutrition status based on gestational body mass index. Anthropometry taken from the 24th week of gestation

Table 2 Anthropometric characteristics of children from the NUTTSEA cohort

\begin{tabular}{|c|c|c|c|}
\hline & Category & Media \pm Standar Deviation, Average 2018 & $\mathrm{Cl} 95 \%$ \\
\hline \multirow[t]{3}{*}{ Age } & Months completed & $7.35 \pm 2.08$ & $7.08-7.62$ \\
\hline & Boys & $7.3 \pm 2.08$ & $6.94-7.66$ \\
\hline & Girls & $7.4 \pm 2.08$ & $7.01-7.84$ \\
\hline \multirow[t]{2}{*}{ Sex } & Boys & $57.5 \%$ & $0.51-0.63$ \\
\hline & Girls & $42.5 \%$ & $0.36-0.48$ \\
\hline Weight & $\mathrm{Kg}$ & $7.74 \pm 1.07$ & $7.60-7.88$ \\
\hline Length & $\mathrm{Cm}$ & $67.30 \pm 5.42$ & $66.60-68.00$ \\
\hline \multirow[t]{5}{*}{ Nutrition satus (Weight / Age) } & Moderate under weight & 4.76 & $0.02-0.08$ \\
\hline & Mild under weight & 22.08 & $0.17-0.27$ \\
\hline & Normal & 64.5 & $0.58-0.70$ \\
\hline & PROW $^{a}$ & 6.93 & $0.04-0.11$ \\
\hline & Overweight & 1.73 & $0.00-0.04$ \\
\hline \multirow{4}{*}{$\begin{array}{l}\text { Nutrition status } \\
\text { (Lenght / Age) }\end{array}$} & Severe low length & 2.16 & $0.00-0.05$ \\
\hline & Moderate low length & 6.49 & $0.03-0.10$ \\
\hline & Mild low length & 24.68 & $0.19-0.30$ \\
\hline & Normal & 66.67 & $0.60-0.72$ \\
\hline \multirow{7}{*}{$\begin{array}{l}\text { Nutrition status } \\
\text { (Weight / Length) }^{\text {b }}\end{array}$} & Severe malnutrition & 0.87 & $0.00-0.03$ \\
\hline & Moderate malnutrition & 3.03 & $0.01-0.06$ \\
\hline & Mild malnutrition & 14.72 & $0.10-0.19$ \\
\hline & Normal & 67.53 & $0.61-0.73$ \\
\hline & PROW $^{a}$ & 7.79 & $0.04-0.12$ \\
\hline & Overweight & 5.63 & $0.03-0.09$ \\
\hline & Obesity & 0.43 & $0.00-0.03$ \\
\hline
\end{tabular}


Table 3 Characterization of diet patterns by factor analysis in relation to the main components of diet

\begin{tabular}{|c|c|c|c|}
\hline & Processed foods & Occidental & High in sugar \\
\hline Vegetables & - & - & - \\
\hline Fruits high glycemic index & - & 0.3842 & - \\
\hline Fruits & - & - & - \\
\hline Low-fat cereals & - & - & - \\
\hline Cereals with sugar & - & 0.3035 & - \\
\hline Desserts & - & - & 0.3611 \\
\hline White bread and flours & - & - & - \\
\hline Soups & 0.3000 & - & - \\
\hline Corn & - & 0.3227 & - \\
\hline Red meats & - & - & - \\
\hline Chicken & - & - & - \\
\hline Fish and seafood & - & - & - \\
\hline Processed meats & 0.3588 & - & - \\
\hline Legumes & - & - & - \\
\hline Egg & - & - & - \\
\hline Liquid dairy & - & - & - \\
\hline High-fat dairy & - & 0.3182 & - \\
\hline Oils & - & - & - \\
\hline Fats & 0.3608 & - & - \\
\hline Other cereals & - & - & - \\
\hline Snack & 0.3705 & - & - \\
\hline Simple water & -0.3980 & - & - \\
\hline Sugary drinks & - & - & - \\
\hline Sweeteners & - & - & 0.4860 \\
\hline Coffee & - & - & 0.5222 \\
\hline
\end{tabular}

milk products $(0.31)$, and the pattern with a high sugar factor was characterized by desserts (0.3), sweeteners (0.4) and coffee with added sugar (0.5).

The diet analysis clearly shows the high consumption of processed and energetically dense foods, which could have been incorporated into the family diet due to their low cost and easy access and availability.

Bivariate analysis, relation between the mother's BMI and the minor's nutritional status

The results of the bivariate analysis for the association between the mothers' post-pregnancy BMI and the minors' nutritional status were statistically significant (p.0.05). An association was found between mothers with low weight and minors with moderate malnutrition ( $p$ 0.05); mothers with normal weight were linked to a normal nutritional status in minors (p 0.01); mothers who were overweight were associated with PROW ( $p$ 0.00 ) and with overweight ( $p$ 0.00) in minors and mothers who were obese were associated with an obesity nutritional status in minors (p 0.00).

\section{Logistic regression analysis of the socioeconomic variables, including the mother's nutritional status}

The results of the logistic regression model used to determine the association between overweight and obesity in women and socioeconomic variables, are shown in Table 4. Women who experience severe food insecurity (p 0.01, CI 0.00-0.31) have 1.17 higher risk of being overweight and obese, than those who have food security. The findings also showed that not belonging to a social program ( $\mathrm{p} .02$, CI $0.01-0.68$ ) leads to 1.87 times greater possibilities of suffering the studied conditions, compared to those who belong to a program. Having a health problem such as hypertension or diabetes ( $\mathrm{p} 0.05$, CI 0.86-2.05) results in having 1.5 times higher possibilities of being overweight or obese, compared to those who have no pathology. Being a smoker (p 0.05, CI $0.80-1.37$ ) was positively associated with the abovementioned conditions and there is a 1.1 higher risk of being overweight or obese than those who did not report being smokers. Consumption of the dietary pattern of processed foods and fat (p 0.001, CI 0.38-0.87), characterized by industrialized soups, snacks and processed meats, led to a 1.5 times risk increase for BMI, compared to those who consumed Western patterns and those that were high in sugar. Finally, although it is not significant, there is a tendency towards overweight and obesity in women who are in the second tertile of income from head of household (p 0.01, CI 0.49-1.32).

\section{Discussion}

The NUTTSEA cohort is a study that analyzes the interaction and influence of socioeconomic determinants as risk factors for overweight and obesity in mothers, and how this in turn affects the nutritional status of the offspring. Our results show evidence of a significant positive association between intergenerational transmission of obesity and the mother's socioeconomic aspects.

An excessive weight increase during pregnancy has been associated with overweight and obesity in postpartum women $[18,19]$. In the NUTTSEA cohort we were able to observe that the combined prevalence of both conditions during pregnancy was $49.7 \%$ and 1 year after the survey it was $53.2 \%$. Although the association was not statistically significant, the prevalence increased by almost four percentage points.

The joint prevalence of overweight and obesity in minors in the NUTTSEA cohort was $6 \%$ and for PROW it was $7.9 \%$, which suggests a future increase in the prevalence of both conditions. This information may be compared to data from the 2016 ENSANUT survey, whose prevalence was $12.3 \%$ [20] and data from the 2015 
Table 4 Main results of the logistic regression regarding the determinants of overweight and maternal obesity

\begin{tabular}{|c|c|c|c|c|}
\hline Overweight / Obesity & Prevalence \% & Odds Ratio $\left(^{*}\right)$ & $95 \% \mathrm{Cl}$ & $\boldsymbol{P}$ Value \\
\hline \multicolumn{5}{|l|}{ Age } \\
\hline Tercil 1 & 36.8 & - & - & - \\
\hline Tercil 2 & 33.3 & 2.928513 & 0.47 .18 .0 & - \\
\hline Tercil 3 & 29.8 & .9201129 & $0.11-7.29 \mathrm{~s}$ & - \\
\hline \multicolumn{5}{|l|}{ Marital status } \\
\hline Single & 7.7 & - & - & - \\
\hline Married & 29 & 4.120726 & $0.18-90.86$ & - \\
\hline Free union & 63.2 & 3.401186 & $0.17-65.97$ & - \\
\hline \multicolumn{5}{|c|}{ Employment of Family Chief } \\
\hline Remunerated & 2.1 & - & - & - \\
\hline Unpaid & 89.1 & .0757522 & $0.00-19.45$ & - \\
\hline Unemployed & 8.66 & .6922784 & $0.00-21.45$ & - \\
\hline \multicolumn{5}{|l|}{ Family Chief Income } \\
\hline Tercil 1 & 36.6 & - & - & - \\
\hline Tercil 2 & 33.4 & .7917301 & $0.49-1.30$ & $* *$ \\
\hline Tercil 3 & 29.9 & .2105857 & $0.01-2.71$ & - \\
\hline \multicolumn{5}{|l|}{ Total income } \\
\hline Tercil 1 & 36.8 & - & - & - \\
\hline Tercil 2 & 30.7 & 9.405535 & $0.82-10.75$ & - \\
\hline Tercil 3 & 32.4 & 10.36989 & $0.45-23.87$ & - \\
\hline \multicolumn{5}{|l|}{ Mother occupation } \\
\hline Remunerated & 19 & - & - & - \\
\hline Unpaid & 80.9 & 3.622143 & $0.36-35.69$ & - \\
\hline \multicolumn{5}{|l|}{ Level of education } \\
\hline Low & 67.9 & - & - & - \\
\hline High & 32 & 1.163893 & $0.21-6.33$ & - \\
\hline P. Processed foods & 100 & 1.5816062 & $0.38-1.87$ & $*$ \\
\hline P. Occidental & 100 & .7709485 & $0.47-1.25$ & - \\
\hline P. High in sugar & 100 & 1.157448 & $0.64-2.07$ & - \\
\hline \multicolumn{5}{|l|}{ Smokes } \\
\hline No & 95.6 & - & - & - \\
\hline Yes & 4.3 & 1.1299077 & $0.80-1.37$ & $* * *$ \\
\hline \multicolumn{5}{|l|}{ Alcohol } \\
\hline No & 72.2 & - & - & - \\
\hline Yes & 27.7 & 1.101313 & $0.25-4.80$ & - \\
\hline \multicolumn{5}{|l|}{ Municipality } \\
\hline Temixco & 52.8 & - & - & - \\
\hline E. Zapata & 21.2 & .4058108 & $0.05-2.78$ & - \\
\hline Xochitepec & 25.9 & 1.595282 & $0.30-8.46$ & - \\
\hline \multicolumn{5}{|l|}{ Social program } \\
\hline Yes & 18.1 & - & - & - \\
\hline No & 81.8 & 1.0877091 & $0.01-0.68$ & $* *$ \\
\hline \multicolumn{5}{|l|}{ Food safety } \\
\hline Safety & 45.8 & - & - & - \\
\hline
\end{tabular}


Table 4 Main results of the logistic regression regarding the determinants of overweight and maternal obesity (Continued)

\begin{tabular}{lllll}
\hline Overweight / Obesity & Prevalence \% & Odds Ratio $\left(^{*}\right)$ & $95 \% \mathrm{Cl}$ & $0.57-11.88$ \\
\hline Mild insecurity & 38.9 & 2.609584 & $0.11-6.33$ & - \\
Moderate insecurity & 10.8 & .8550086 & $0.00-1.31$ & - \\
Severe insecurity & 4.3 & 1.1700472 & - \\
Current health problem & & & $0.86-2.05$ & \\
No & 88.3 & - & - \\
Yes & 11.6 & 1.572707 & - \\
Pregnancy health problem & & & - & - \\
No & 70.5 & -7714542 & $0.12-4.87$ \\
Yes & 29.4 & &
\end{tabular}

$<0.001^{*}<0.01^{* *}<0.05^{* * *}$ Odds ratio adjusted by age and marital status

National Survey of Boys, Girls and Women, which reported a prevalence of $5.2 \%$ [21]. These national surveys considered 5 year old minors as a reference and our study only considered minors who were 1 year old. Today, no data exist on overweight and obesity in breastfeeding babies.

Our results show that excess weight in the mother is significantly associated with PROW and overweight ( $\mathrm{p}$ 0.05 ) in minors. We were able to observe that overweight in mothers was associated with PROW (p 0.00) and with overweight $(\mathrm{p} 0.00)$ in a statistically significant way. Other studies report similar findings, where overweight and obesity in parents lead to the development of these conditions in minors [9-11], and relate the appearance of chronic and metabolic diseases in adult children of obese parents $[7,22,23]$. With respect to the socioeconomic determinants, we were able to observe that severe food insecurity was significantly associated ( $p$ 0.02) with an increase in BMI in mothers. These results agree with those from other investigations which relate the development of overweight or obesity with some degree of food insecurity, since this is considered to be a factor predisposing to access and availability of dense energy foods that are high in saturated fats, as well as processed foods [24, 25].

We explored the association and influence on nutritional status of not belonging to a social program, specifically its effect on overweight and obesity, and found a positive association ( $\mathrm{p}$ 0.02, CI 0.01-0.68). Our results agree with some studies showing that these programs provide orientation and education in matters of nutrition, as well as monetary incentives to improve food intake, or else participants receive food supplements [26, 27].

With respect to lifestyles, we found that consumption of a dietary pattern of processed food, characterized by industrialized soups, snacks and processed meats, was related to the studied conditions ( $\mathrm{p} 0.001$, CI 0.38-0.87). Other studies of dietary patterns associate this type of pattern with weight gain, abdominal obesity or diabetes [28-30]. Another studied lifestyle was that of tobacco smokers, where we found a significant connection between smoking and BMI in women (p 0.05, CI 0.801.37). Other studies also talk about weight gain with cigarette consumption and this is considered to be a risk factor for chronic diseases [31]. We found evidence that dietary patterns characterized by processed foods are influenced by family economics, access and availability. It has also been observed that the most vulnerable households are more prone to consumption of this pattern since the densely energetic foods are cheaper.

The study's limitations are that some women who were renting moved to a different address and also changed their phone numbers; this prevented us from being able to contact them, thus representing a loss in the sample. In some cases, there was a death of a minor, for which the mothers were not surveyed. With respect to the economic indicators, it is worth mentioning that we only reported the perception of income since we do not have an economic index to estimate the families' real incomes.

\section{Conclusion}

Our results highlight the importance of paying attention to risk factors present since the gestational stage, in view of the fact that during this period the mother's nutritional status has an influence on the offspring's growth and development, and it is during this stage of early infancy when the health conditions of the adult stage are defined. This investigation shows evidence of a positive and significant association between the intergenerational transmission of overweight and obesity and the mother's socioeconomic aspects. These evidences could be considered in the design and implementation of interventions and/or public health programs, as strategies for the prevention of overweight and obesity in the motherchild binomial. 


\section{Abbreviations}

ENSANUT: National Health and Nutrition Surveys (Abbreviation in Spanish); BMI: Body mass index; NUTTSEA: Name of the cohort; L/A: Length by age; W/A: Weight by age; WHO: World Health Organization; PROW: Possible risk of overweight; ELCSA: Escala Latinoamericana y del Caribe de Seguridad Alimentaria

\section{Acknowledgments}

Not applicable.

\section{Authors' contributions}

AA Designed the study, as well as being the principal investigator of the project. CT Performed the quantitative analysis of the study and participated in the design of the study. EO Participated in the writing and revision of the article. ORParticipated in the writing and revision of the article. The author(s) read and approved the final manuscript.

\section{Authors' information}

Not applicable.

\section{Funding}

Not applicable.

\section{Availability of data and materials}

Applicable.

\section{Ethics approva}

The project is approved by the ethics and research committees of the National Institute of Public Health.

\section{Consent for publication}

Not applicable.

\section{Competing interests}

All authors declare no conflict of interest.

\section{Received: 1 October 2019 Accepted: 23 April 2020}

\section{Published online: 11 May 2020}

\section{References}

1. Kelly T, Yang W, Chen S, Reynolds K, He J. Global burden of obesity in 2005 and projections to 2030. Int J Obes. 2008;32(9):1431-7.

2. Rivera J, Barquera S, Campirano F, Campos I, Safdie M, Tovar V. Epidemiological and nutritional transition in Mexico: rapid increase of noncommunicable chronic diseases and obesity. Public Health Nutr. 2002;5(1): $113-22$

3. Gutiérrez J, Rivera-Dommarco J, Shama-Levy T, Villalpando-Hernández S, Franco A, Cuevas-Nasu L, et al. Encuesta Nacional de Salud y Nutrición. Inst Nac Salud Pública. 2012;2012:200. https://ensanut.insp.mx/informes/ ENSANUT2012ResultadosNacionales.pdf . Accessed 25 Oct 2018.

4. Hernández-Ávila M, Rivera J, Shama L, Cuevas L, Gómez L, Gaona E, et al. Encuesta Nacional de Salud y Nutrición de Medio Camino 2016. Inst Nac Salud Pública. 2016. p. 2016. https://ensanut.insp.mx/informes/ENSANUT2 012ResultadosNacionales.pdf . Accessed 25 Oct 2018

5. Conall M, Ávalos G, O'Reily M, O'Sullivan E, Gaffney G, Dunne F. ATLANTICDIP: raised maternal body mass index adversely affects maternal and fetal outcomes in glucose-tolerant women according to International Association of Diabetes and Pregnancy Study Groups criteria. J Clin Endocrinol Metab. 2012:97(4):608-12.

6. Fraser A, Tilling K, Macdonald-Wallis C, Sattar N, Brion M, Benfield L, et al Pauper apprenticeship in early nineteenth century Ontario. J Fam Hist. 1996; 21(2):144-71.

7. Mueller N, Garmendia ML, Reyes M, Corválan C, Pereira A, Uauy R. Female offspring birth weight is associated with body mass index, waist circumference and metabolic syndrome in Latin American women at 10-years postpartum. Diabetes Res Clin Pract. 2018;138:90-8

8. Black RE, Victora CG, Walker SP, Bhutta ZA, Christian P, De Onis M, et al. Maternal and child undernutrition and overweight in low-income and middle-income countries. Lancet. 2013;382(9890):427-51.
9. Classen TJ. Measures of the intergenerational transmission of body mass index between mothers and their children in the United States, 1981-2004. Econ Hum Biol. 2010;8(1):30-43.

10. Klünder-Klünder M, Cruz M, Medina-Bravo P, Flores-Huerta S (2011). Padres con sobrepeso y obesidad y el riesgo de que sus hijos desarrollen obesidad y aumento en los valores de la presión arterial. Do Child parents with overweight Obes have an increased risk Dev Obes Chang blood Press. 68(6): 438-446.

11. Mei H, Guo S, Lu H, Pan Y, Mei W, Zhang B, et al. Impact of parental weight status on children's body mass index in early life: evidence from a Chinese cohort. BMJ Open. 2018;8(6):e018755.

12. Wong MS, Showell NN, Bleich SN, Gudzune KA, Chan KS. The association between parent-reported provider communication quality and child obesity status: variation by parent obesity and child race/ethnicity. Patient Educ Couns. 2017:100(8):1588

13. Newton S, Bralthwalte D, Akinyemiju T. Socio-economic status over the life course and obesity: systematic review and meta-analysis. PLoS One. 2017; 12(5):1-15.

14. Figueroa D. Obesidad y Pobreza : marco conceptual para su análisis en latinoamérica. Saúde Soc São Paulo. 2009;18:103-17.

15. Arredondo A, Torres C, Orozco E, Pacheco S, Huang F, Zambrano E, et al. Socio-economic indicators, dietary patterns, and physical activity as determinants of maternal obesity in middle-income countries: evidences from a cohort study in Mexico. Int J Health Plann Manag. 2018;34(1):1-13

16. Arredondo A, Torres C, Orozco E, Pacheco S, Aragón A, Huang F, et al. Indicadores socioeconómicos de la obesidad materna en México y Francia. Análisis comparado de dos cohortes. Rev Salud Pública. 2018; 20(2):245-53.

17. Organización de las Naciones Unidad para la Agricultura y la Alimentación. Escala Latinoamerica y Caribeña de Seguridad Alimentaria: Manual de uso y aplicaciones. 2012;(1):10-5.

18. Gunderson E. Childbearing and obesity in women: weight before, during, and after pregnancy. Obstet Gynecol Clin N Am. 2009;36(2):317-32.

19. Mamun A, Kinarivada M, O'Callighan M, Williams G, Najman J, Callaway L. Associations of excess weight gain during pregnancy with long-term maternal overweight and obesity: evidence from 21 y postpartum followup. Am J Clin Nutr. 2010;91(5):1336-41.

20. Shama-Levy T, Cuevas-Nasu L, Gaona-Pineda B, Gómez-Acosta L, Morales-Ruán M, Hernández-Ávila M, et al. Sobrepeso y obesidad en niños y adolescentes en México, actualización de la Encuesta Nacional de Salud y Nutrición de Medio Camino 2016. Salud Publica Mex. 2018; 60(3):244-53.

21. Instituto Nacional de Salud Pública; UNICEF México. Encuesta Nacional de Niños, Niñas y Mujeres 2015. Vol. 136, Instituto Nacional de Salud Pública y UNICEF Mëxico. 2007. https://www.unicef.org/mexico/spanish/UNICEF_ ENIM2015.pdf. Accessed 27 Oct 2018.

22. Boney CM. Metabolic syndrome in childhood: association with birth weight, maternal obesity, and gestational diabetes mellitus. Pediatrics. 2005;115(3): e290-6

23. Linares J, Corvalán C, Galleguillos B, Kain J, González L, Uauy R, et al. The effects of pre-pregnancy BMl and maternal factors on the timing of adiposity rebound in offspring. Obesity. 2016:24(6):1313-9.

24. Dhurandhar E. HHS public access; 2017. p. 88-92.

25. Morales-Ruán M, Méndez-Gómez I, Shama-Levy T, Valderrama-Álvarez Z, Melgar-Quiñones H. La inseguridad alimentaria está asociada con obesidad en mujeres adultas de México. Salud Publica Mex. 2014;56(1): 54-61.

26. Ryan-Ibarra S, Sánchez-Vaznaugh E, Leung C, Induni M. The relationship between food insecurity and overweight/obesity differs by birthplace and length of US residence. Public Health Nutr. 2017;20(4):241-50.

27. Diez-Canseco F, Saavedra-García L. Social programs and reducing obesity in Peru: reflections from the research. Rev Peru Med Exp Salud Publica. 2017; 34(1):105-12.

28. Rabi D, Edwards A, Southern D, Svenson L, Sargious P, Norton P, et al. Association of socio-economic status with diabetes prevalence and utilization of diabetes care services. BMC Health Serv Res. 2006:6:1-7.

29. Kimokoti RW, Gona P, Zhu L, Newby PK, Millen BE, Brown LS, et al. Dietary patterns of women are associated with incident abdominal obesity but not metabolic syndrome 1-3. J Nutr. 2012;142:1720-7. 
30. Flores M, Macias N, Rivera M, Lozada A, Barquera S, Rivera-Dommarco J, et al. Dietary patterns in Mexican adults are associated with risk of being overweight or obese. J Nutr. 2010;140(10):1869-73.

31. Dare S, Mackay D, Peli J. Relationship between smoking and obesity: a cross-sectional study of 499,504 middle-aged adults in the UK general population. PLoS One. 2015;10(4):1-12.

\section{Publisher's Note}

Springer Nature remains neutral with regard to jurisdictional claims in published maps and institutional affiliations.

Ready to submit your research? Choose BMC and benefit from:

- fast, convenient online submission

- thorough peer review by experienced researchers in your field

- rapid publication on acceptance

- support for research data, including large and complex data types

- gold Open Access which fosters wider collaboration and increased citations

- maximum visibility for your research: over $100 \mathrm{M}$ website views per year

At BMC, research is always in progress.

Learn more biomedcentral.com/submissions 